\title{
Application of Cost-Volume-Profit Analysis in Decision-Making by Public Universities in Vietnam
}

\author{
Oanh ThiTuLE ${ }^{1}$,Phong ThiThu TRAN ${ }^{2}$, Thuan VanTRAN, Cong Van NGUYEN ${ }^{4}$
}

Received: March 30, 2020 Revised: April 11, 2020 Accepted: May 01, 2020

\begin{abstract}
This paper aims to examine the application of cost-volume-profit (CVP) analysis by public universities in Vietnam. In the context where Vietnam is gradually transferring financial autonomy to public universities, the conduct of a CVP analysis in relation to these public universities is particularly urgent. Research samples were collected in 2018 and 2019 by surveying Vietnamese public universities. After collection, the data is synthesized by excel file, conformity check, data cleansing and data analysis on SPSS software by tools such as Frequency statistics, price statistics, and means. The results show that: (1) universities used the CVP analysis in decision-making, (2) information related to the CVP analysis used for decision-making by administrators remained simplistic and lacked cost-control details, and (3) the application of the CVP analysis by university administrators for decision-making was neither comprehensive nor coordinated. The findings also show that, given the current conditions in Vietnam, increasing the governance in public universities is essential, as is contributing to reducing costs, increasing universities' income, providing the best service to students, and improving the quality of training. The study calls for the flexible application of the CVP analysis, which will provide information to help managers at Vietnamese public universities make the best decisions.
\end{abstract}

Keywords : CVP Analysis, Decision Making, Public Universities, Vietnam.

JEL Classification Code: M10, M21, M41

\section{Introduction}

Vietnamese public universities operate primarily on the mechanism of state budget allocations. This leads to the passive way in management activities and financial management in particular (Tran, 2016). To overcome these limitations, the Government of Vietnam has handed over autonomy to public universities, by the Prime Minister's Decree No. 16/2015/ND-CP on February 14, 2015

${ }^{1}$ First Author. University of Labour and Social Affairs, Hanoi, Vietnam. Email: oanhletu@gmail.com

${ }^{2}$ Hanoi Open University, Vietnam. Email: thuphonghou@gmail.com ${ }^{3}$ Associate Professor, The National Economics University, Vietnam. Email: tranthuan19@ymail.com

${ }^{4}$ Corresponding Author. Professor, The National Economics University, Vietnam [Postal Address: 207 Giai Phong Road, Dong Tam Ward, Hai Ba Trung District, Hanoi, 113068, Vietnam] Email: anhcongtuan@gmail.com

(c) Copyright: The Author(s)

This is an Open Access article distributed under the terms of the Creative Commons Attribution Non-Commercial License (http://Creativecommons.org/licenses/by-nc/4.0/) which permits unrestricted noncommercial use, distribution, and reproduction in any medium, provided the original work is properly cited.
(Government, 2015). Facing integration requirements and the application of autonomy, Vietnamese public universities needed to make continuous efforts to improve the quality of training, prestige and competitiveness (Le, 2017). In order to enhance control of costs, revenues and profits, and promoting the quality of training, the leadership of Vietnam's public universities is forced to pay attention to decision-making, including information derived from Cost-Volume-Profit (CVP) analysis. The actual survey results show that the financial information at the Vietnamese public universities was limited to some basic data such as: (i) Expense elements such as salaries, scholarships, outside services, etc. (according to the State budget index), there was lack of variable costs and fixed costs data, which was the basis for making decisions with each increasing options or costs controlling to each department; (ii) Information on budgeting that complied with the norms, regimes and standards of the State; (iii) Information on management decentralization was not yet associated with the responsibility for cost control of departments; (iv) Information on costs, break-even points, training costs for a student was not synchronized, based on the personal experience of the administrators. Therefore, the 
decisions of the leaders were focused on the short term and not associated with more modern management methods such as responsibility accounting in order to assign expenditures and revenues to each department; it would produce balanced scorecard to promote the power of the system synchronously, towards achieving the universities goals in the long term. Limited information provision in Vietnamese public universities has reduced their effectiveness.

The CVP analysis is a technique whereby each change in cost, volume, and price will comes across with profit (Kaplan \& Atkinson, 2007). Over time, the CVP analysis has become increasingly popular and generated useful information, related to control production output, plan and make decisions such as types of products, their volume, expanding or narrowing a product line, break-even point of output, revenue and time, and consumption to achieve the target profit (Bauer \& Bauer, 2018). According to Gean and Gean (2015), the CVP analysis is an important method to capture the reaction and the relationship between activities, costs, volumes and profits, providing a wealth of relevant information useful for decisions in short term. The CVP analysis is aimed at determining the output that adds value to the business, emphasizes the impact of fixed costs, break-even points, target profits that determine sales volume and revenue estimates. Making price decisions and price structures is simpler when using the CVP analysis. In addition, the CVP analysis provides users with information about the safety margin of a fall in sales that can be maintained before sales reach break-even, and imminent losses if sales fall in the next stage.

The CVP analysis, applied to universities like businesses, includes determining fixed costs, variable costs, breakeven points for each course; number of required students in each course; continued training, narrow or stop for classes, courses, or majors; how many training courses are needed for the school to meet its profit goals, etc. The application of the CVP analysis model analyzes the cost of the number of students and the income, determine the minimum number of students trained to break even, balance the budget and determine enrollment targets for the next year, etc., is essential. Therefore, this study considers and evaluates: (i) the situation of cost classification for the CVP analysis in Vietnamese public universities, (ii) the reality of using CVP analytical information to make decisions in Vietnamese public universities, (iii) the request information on the CVP analysis from university leaders to make a decision, and (iv) the suggestions for applying the CVP analysis to decisionmaking in Vietnamese public universities.

\section{Literature Review}

The CVP analysis is conducted based on a series of basic assumptions about the relevant parameters that limit the relevant output volume: total cost, unit price, unit cost variable, and unit margin. Using the information from a CVP analysis, managers will find the relationship between cost (C), output volume (V) and profit (P). The CVP analysis is an effective way to forecast costs, realize target profits, and analyze a company's decisions. Until now, the CVP analysis has been more widely used in business than in education.

\subsection{Studies on CVPAnalysis in Business}

Researching the use of the CVP analysis in decisionmaking, Buşan and Dina (2009) showed the CVP relationship as the way of developing total revenue, total cost and operating profit. The volume of production, unit prices, unit variable cost, or fixed cost help managers answer various questions such as: How will income and costs be affected if the volume sold out is unchanged? What will happen if unit prices increase or decrease? Whether to expand business in foreign markets?

Fixed costs in hotels tend to be high, so when the revenue drops significantly below break-even, the losses will be high. Therefore, the traditional cost-volume-profit analysis model is widely used in the hotel industry to determine break-even point. Phillips (1994) looked at the basic cost-volume-profit analysis model and described how to include uncertainties in the decision-making process. It has therefore been shown to determine probabilities for different expected levels of return, and also to consider some other inherent operational difficulties of the basic cost-volume-profit analysis model.

As regards the multidisciplinary company analysis based on a micro approach, Kim (2015) developed a micro approach to find break-even points and target profit. This study attempted to develop a systematic approach to refine the answers of two basic issues in the CVP analysis: break-even point and target profit. Jiang and Shen (2017) conducted an analysis of the restaurant's cost, break-even, safe operation level, and the impact of restaurant profit due to changes switch factor. This result helped the restaurant manager make better decisions by analyzing multi-element positioning in the service industry and examining the relationship between the key elements of the service industry and the profit due to factor change.

Punniyamoorthy (2017) stated that the CVP analysis was a tool to assess the impact of changes in value, volume, variable costs or fixed costs on benefits. Moreover, CVP was the basis for pricing, deciding short-term options, target costs and value of the exchange.

Lulaj and Etem Iseni (2018) argued that the CVP analysis was an important content to plan and make decisions in business. The research was carried out in manufacturing and service businesses, using a combination of econometric models to make this research accurate and effective. The results showed that the amount of produced products had 
a positive impact on the sales for service companies and increased profits for the manufacturing business, there was an important relationship between production and sales.

Stoenoiu (2018) conducted a study on the sensitivity of the indicators used in the CVP analysis. The research was based on the need to optimize and manage costs due to unforeseen economic events in all areas. Therefore, this study analyzed the dependency relationship among the three CVP indices to highlight the need for permanent monitoring and optimization of these variables to provide a reliable basis for management decisions. The research showed the extent and significance of the changes toward one or more variables due to the direct relationship and inversion between these variables.

Referring to the CVP analysis, Enyi (2019) compared the effect of the weighted contribution margin (WCM) and the reversed contribution margin ratio (RCMR). The result showed that WCM lacked analytical efficiency and generates suboptimal products mix because it ignored the inverse relationship between a product's contribution margin ratio (CMR) and its break-even point (BEP). The paper suggested the use of the RCMR with the effects of the CMR/ BEP measurement.

\subsection{Studies on CVP Analysis in the Education Sector and the Public Sector}

The research by Witte and López-Torres (2015) was based on the previous study with inputs, outputs and contextual variables, as well as the data sources used in the articles to conduct the research in the education. The study clearly showed the difference in effectiveness between education and economics. Regarding quantitative research, Upping and Oliver (2012) conducted the survey with 78 financial directors of public universities in Thailand to assess factors affecting the change of accounting information for planning and control purposes. The research showed the basic factor affecting the information conversion process was the low efficiency due to the lack of technology resources and the staff had only practical knowledge about private enterprises. The study also emphasizes the role of the information system - including CVP analysis - in supporting the operational environment under government budget reduction and strengthening financial responsibility in public universities.

Agasisti and Johnes (2010) studied the heterogeneity and the effectiveness evaluation in Italian universities resulting from the rapid change of the higher education environment in Europe since the mid-1980s when the Italian government transfers financial autonomy to universities. The study had useful information on changes in cost structure and technical efficiency that lead to a decline in profitability in typical universities. Liu, Forgione, and Younis (2012) compared the CVP structure of large urban hospitals with non-profit teaching activities and small-profit hospitals without rural teaching activities. The result showed that large, non-profit teaching hospitals in urban areas had higher fixed costs and lower variable costs, lower revenue and return on assets (ROA). In contrast, non-profit rural hospitals tended to have lower fixed costs, higher variable costs, higher revenues and higher ROA.

Some authors are interested in the aspect of applying CVP analysis in the education sector and the public sector such as Goddard (2006), Cropper and Cook (2000). These studies use survey methodology to evaluated the application of the CVP analysis to the accounting work of universities and showed the benefits of applying this technology to universities. However, studies indicated that the challenge of using a cost-based operating system is complex and expensive, so the benefits should be weighed against the cost. Goddard (2006), when investigated the relationship between accounting and new public management (NPM) at the UK Local Government tried to consider management from the perspective of participants and pointed out the accounting knowledge and NPM related to governance and local government responsibilities. Cropper and Cook (2000) described the current state of cost in higher education, reviewed recently-published documents and analyzed organizations' progress in implementing a CVP analysis. The study results found that the implementation of the CVP analysis is slow and, therefore, it is necessary to increase the pressure of change from donor agencies and central government. At the same time, research results have shown that many universities are not happy with their cost accounting system and are looking to change them. With the financial resources available to universities becoming increasingly limited, it is necessary to offset the costs from the revenues of the courses to better manage the source.

The balanced scorecard is an effective management tool. Philbin (2011) points out that developing and applying a balanced scorecard with financial and non-financial measures can improve governance efficiency of governance in universities. From there, it will bring intangible benefits to stakeholders such as students, faculty, the state and the whole society. Research has identified ways to develop balanced scorecard-based reports that include economic and non-economic measures to improve university management performance by providing tangible benefits for stakeholders.

To identify barriers for university and industry cooperation, and develop recommendations for the internal ecosystem of technology commercialization, Alibekova, Tleppayev, Medeni, and Ruzanov (2019) conducted a survey of experts. Survey results showed that the main barriers for cooperation between universities and the industry are: lack of resources to build university-industry links, lack of time due to high teaching load, poor qualification of technology transfer managers, and incomplete connection with the industry. Based on the results of expert surveys, the study proposes an 
ecosystem development to commercialize university-based technologies, in which the following economic activities are important: human resources, finance and intellectual property management system and intermediary infrastructure.

The study by Abdullahi, Bello, Mukhtar, and Musa (2017) on the use of the CVP analysis as a management tool for decision-making in small businesses of Bayero University, Kano, was conducted on the main database that collected by structured questionnaires. The hypotheses were tested by the Mann-Whitney U-test and the Pearson correlation coefficient. The study concluded that small businesses were less interested in using the CVP analysis and other management accounting tools. Since then, the study also recommended the use of the CVP analysis in small businesses in general and small businesses in universities in particular to improve productivity.

In the study of factors affecting the industry and university cooperation in education in the hotel industry in Vietnam, Nguyen \& Nguyen (2020) considered that the process factor has the most positive factor, followed by the contextual factor. The study also revealed that the benefit factors were significantly associated with educational cooperation, affecting university and industry hotel allianecs. Le (2017) considered management accounting as a tool for financial autonomy at public universities, in which, the author proposed classification of variable costs and fixed costs; identify the object of cost collection by training level and training system; assess the cost fluctuation impact on the financial performance of the school. The mention of the CVP analysis for short-term decision-making is unclear.

Some other indirect studies related to finance in public universities. Zulfaris, Mustafa, Mahussin, Alam, and Daud (2020) when studying the relationship between student and money management behavior showed that all financial knowledge and socializing of the parents have a positive relationship with money management; meanwhile, peer influence and self-control have a negative relationship with money management. The study also asserts that most students admit they cannot control themselves in managing their money and that their parents are playing an essential role in securing their money management. Sabri, Cook and Gudmunson (2012) when studied about the financial well-being of Malaysian college students that show the experiences of childhood consumers such as the habit of saving contribute to helping students earn a lot of money (saving money, current financial situation, financial management skills) and a level of financial literacy related to financial well-being.

\section{Research Methodology}

The study was conducted by sending questionnaires to the finance departments of 138 public universities in Vietnam.
There were 55 valid answers from 53 public universities. Due to the low response rate (40\%), the sample size of the study was calculated using the following formula (Nguyen \& Nguyen, 2015):

$\mathrm{ntt}=\mathrm{n} * \mathrm{re}$

In which:

$\mathrm{n}$ is the required sample size

$\mathrm{ntt}$ is the minimum sample size in practice

re is the response rate (\%)

According to this formula, the actual sample size required for the study is:

$\mathrm{ntt}=102 *(55 / 138)=41$.

The number of samples collected in this study was 55, which is appropriate for analysis. A total of 55 people participated in this study, of which people who have more than 10 years of work experience accounts for $27 \%$; $49.1 \%$ of respondents have from 5 to 10 years of work experience $(20 ; 36.4 \%)$. Furthermore, $76.4 \%$ of respondents have a postgraduate degree, the remaining have a university degree. The results of the demographic survey show that respondents are suitable subjects to collect relevant information on the management accounting application of public universities.

Regarding the surveyed universities, among 53 universities, 16 are fully autonomous, 29 are partially autonomous and eight are not autonomous. In terms of age, 25 universities have operated over 50 years (accounting for $47.2 \%), 16$ universities have operated from 20 to 50 years (accounting for $30.2 \%$ ), only a small number of universities have operated for less than 20 years. Regarding location, the majority of universities are located in the North $(30 ; 56.6 \%)$, the number of universities located in the Central and South are relatively similar (20.8\% and $22.6 \%$ respectively). Compared to the overall distribution level of 138 Universities (Vu, 2017), universities located in the North accounts for 54\%; universities located in the Central and the South are $20 \%$ and $27 \%$ respectively. Thus, the distribution of the sample of 53 universities is appropriate (see Table 1).

The collected data is processed on SPSS 20 software combined with analyzing and comparing the results with statistical secondary data to achieve the research objectives. Steps of the research are as follows: (i) entering data into excel file, checking the validity of answers, eliminating blank and incomplete answers; (ii) checking and cleaning data; (iii) analyzing data on SPSS 20 software with the following tools: Frequency statistics and mean. 
Table 1: Characteristics of Vietnamese public universities

\begin{tabular}{|l|l|c|c|}
\hline \multicolumn{2}{|c|}{ The criteria } & $\begin{array}{c}\text { Number of universities } \\
\text { (units) }\end{array}$ & $\begin{array}{c}\text { Percentage } \\
\text { (\%) }\end{array}$ \\
\hline \multirow{4}{*}{ 1. The degree of autonomy } & None autonomy & 8 & 15.1 \\
\cline { 2 - 4 } & Partial autonomy & 29 & 54.7 \\
\cline { 2 - 4 } & Full autonomy & 16 & 30.2 \\
\cline { 2 - 4 } & Grand Total & $\mathbf{5 3}$ & $\mathbf{1 0 0 . 0}$ \\
\hline \multirow{5}{*}{ 2. Age of University } & $<10$ years & 3 & 5.7 \\
\cline { 2 - 4 } & $10-20$ years & 9 & 17.0 \\
\cline { 2 - 4 } & $20-50$ years & 16 & 30.2 \\
\cline { 2 - 4 } & $<50$ years & 25 & 47.2 \\
\cline { 2 - 4 } & Grand Total & $\mathbf{5 3}$ & $\mathbf{1 0 0 . 0}$ \\
\hline \multirow{5}{*}{ 3. Location } & North & 30 & 56.6 \\
\cline { 2 - 4 } & Central & 11 & 20.8 \\
\cline { 2 - 4 } & South & 12 & 22.6 \\
\cline { 2 - 4 } & Grand Total & $\mathbf{5 3}$ & $\mathbf{1 0 0 . 0}$ \\
\hline
\end{tabular}

\section{Research Results}

\subsection{Regarding Operating Expenses}

Cost is an important part of a university's CVP analysis. It is assessed on three dimensions: cost classification, cost reporting and cost allocation. Through a reasonable cost classification, accountants can provide multi-dimensional information. Through detailed reports on variable costs and fixed costs; controllable costs and uncontrollable costs; cost factors; direct and indirect costs universities, administrators will have an appropriate cost assessment and apply it in the CVP analysis.

In terms of cost classification and tracking of operating costs, universities only track cost factors such as salaries, scholarships, outside services, etc. (according to the State budget index), with $100 \%$ of answers being "Yes". Other classifications include variable costs and fixed costs; direct and indirect costs for one student; direct and indirect costs for each department; and controllable and uncontrollable costs which are not emphasized by universities. The percentage of universities that do not classify or track these costs is between $43.6 \%$ and $63.6 \%$. These are necessary costs in management reports, but not yet implemented.

In terms of cost reporting to administrators, the finance departments of universities only report the cost factors while other types of costs such as variable costs and fixed costs; direct and indirect costs for one student; direct and indirect costs for each department; and controllable and uncontrollable costs are not presented (the percentage of
"No" response is between $49.1 \%$ and $72.7 \%$ ). In particular, reporting of controllable and uncontrollable costs receives the least attention, and the rate of non-implementation is $72.7 \%$. Thus, reports providing useful information to the board of administrators in decision-making are not made regularly by public universities.

General cost allocation is always a concern for accountants when providing appropriate cost information for cost-bearing subjects. The more specific the general cost allocation, the more appropriate the information provided for the management's decision-making. The actual survey shows that the general cost allocation is prepared flexibly by universities, and each type of cost has its own allocation; for example, the cost of investment in teaching materials can be allocated by the number of faculty members of the department, and training management expenditures are allocated according to the number of students managed by that department. This flexible allocation is popularly applied by approximately $76.4 \%$ of universities. Moreover, the cost allocation according to the number of students of the entire university accounts for $40 \%$. Not many universities allocate costs according to the number of students of the courses or the number of staff at the departments; the response rate of "No" of these particular survey items were approximately $67.3 \%$ and $81.8 \%$, respectively.

Thus, the cost classification and cost reporting for university administrators' decision-making are conducted by accountants; however, those reports are neither comprehensive nor coordinated. The reports remain simplistic and mainly track costs factors, while other information for cost control 
such as controllable and uncontrollable costs and direct and indirect costs for each department are not prepared or receive the attention of accountants (see Table 2).

\subsection{Information for Decision-Making}

When asked about the use of the CVP analysis when making decision to choose one of many options, 55/55 university administrators said they consulted the accountants' information. This shows that the board of administrators attributes great importance to the accounting information when making decisions. More detailed information for decision making is shown in Table 3.

In terms of frequency, most respondents agreed that the finance departments of universities provide information for the board of administrators' decision-making; the percentage of "agree" and "totally agree" were over $60 \%$. It was found that $81.8 \%$ of respondents used the information to decide the wage of teachers and that about $78.2 \%$ used the information for making decisions about joint training courses. It was also found that $76.4 \%$ used the information for determining tuition fees for short-term training classes. Furthermore, there was

Table 2: Cost Classification, Reporting and Allocation in the Public Universities Vietnam

\begin{tabular}{|c|c|c|c|c|}
\hline \multirow{2}{*}{\multicolumn{2}{|c|}{ The criteria }} & \multicolumn{3}{|c|}{ Actual application (units) } \\
\hline & & \multirow{2}{*}{$\begin{array}{c}\text { Yes } \\
20\end{array}$} & \multirow{2}{*}{$\begin{array}{l}\text { No } \\
35 \\
\end{array}$} & \multirow{2}{*}{$\begin{array}{c}\text { Grand Total } \\
55\end{array}$} \\
\hline 1. Classification & Controlled and uncontrolled cost & & & \\
\hline & $\begin{array}{l}\text { Cost factor (salary, scholarship, outside } \\
\text { services, ...) }\end{array}$ & 55 & 0 & 55 \\
\hline & $\begin{array}{l}\text { Direct and indirect costs (per department, } \\
\text { department, department, ...) }\end{array}$ & 31 & 24 & 55 \\
\hline & Cost per each student & 29 & 26 & 55 \\
\hline & Fixed and variable costs & 29 & 26 & 55 \\
\hline \multirow[t]{5}{*}{ 2. Report } & Controlled and uncontrolled cost & 15 & 40 & 55 \\
\hline & $\begin{array}{l}\text { Cost factor (salary, scholarship, outside } \\
\text { services, ...) }\end{array}$ & 55 & 0 & 55 \\
\hline & $\begin{array}{l}\text { Direct and indirect costs (per department, } \\
\text { department, department, ...) }\end{array}$ & 28 & 27 & 55 \\
\hline & Cost per each student & 26 & 29 & 55 \\
\hline & Fixed and variable costs & 19 & 36 & 55 \\
\hline \multirow[t]{4}{*}{ 3. Allocation criteria } & Specific criteria for each type of cost & 42 & 13 & 55 \\
\hline & The number of officers in each department & 18 & 37 & 55 \\
\hline & The number of students each course & 10 & 45 & 55 \\
\hline & The number of students in university & 22 & 33 & 55 \\
\hline
\end{tabular}

Table 3: CVP analytical information for decision making

\begin{tabular}{|c|c|c|c|c|c|c|c|c|}
\hline \multirow{2}{*}{ Make decision } & \multirow{2}{*}{$\mathbf{N}$} & \multirow{2}{*}{ Mean } & \multicolumn{6}{|c|}{ Percentage (\%) } \\
\hline & & & S1 & S2 & S3 & S4 & S5 & S4 \& S5 \\
\hline 1. Breakeven point for each course & 55 & 3.62 & 3.6 & 3.6 & 29.1 & 54.5 & 9.1 & 63.6 \\
\hline 2. Determine repeat class size & 55 & 3.71 & 1.8 & 9.1 & 21.8 & 50.9 & 16.4 & 67.3 \\
\hline 3. Calculate the unit cost for 1 student & 55 & 3.73 & 1.8 & 7.3 & 21.8 & 54.5 & 14.5 & 69.0 \\
\hline 4. Identify joint training courses & 55 & 3.93 & 0.0 & 5.5 & 16.4 & 58.2 & 20.0 & 78.2 \\
\hline $\begin{array}{l}\text { 5. Calculate the cost of short-term } \\
\text { training courses }\end{array}$ & 55 & 3.82 & 3.6 & 3.6 & 16.4 & 60.0 & 16.4 & 76.4 \\
\hline 6. Set unit price of lecture hours & 55 & 4.04 & 0.0 & 1.8 & 16.4 & 58.2 & 23.6 & 81.8 \\
\hline
\end{tabular}

Notes: S1 (Strong Disagree) and S5 (Strong Agree) 
only a small percentage of respondents who disagreed with using information for decision making (from $0 \%$ to $3.6 \%$ ). For more details, see the comparison that is made in Figure 1:

Regarding mean values, all information serving university administrators' decision-making has high mean values from 3.62 to 4.04 . Information used to make the decision on the unit price for lecture hours has the highest mean value of 4.04, and it is followed by the mean value for using information for making the decision on joint training (mean value of 3.93) and the mean value for using the information to determine tuition fees of short-term courses (3.82). The information that is not used much is the breakeven point for each course (mean value of 3.62).

Therefore, in terms of information used for decisionmaking, according to accountants of public universities, the accounting and finance department provides basic information serving as a basis for the board of administrators; specifically, the department provides information for deciding the wages of teachers, joint training courses, and sizes of repeat classes. Accounting information is a reliable and effective basis for administrators when making decisions related to the opening of short-term training courses, joint training, repeat classes (the scale and break-even points thereof), cost per student, and the wage of teachers.

\subsection{Requirements for the Application of CVP Analysis in Making-Decisions}

In order to evaluate the requirements for the application of the CVP analysis in public universities in Vietnam, this paper evaluates the opinions of the financial department on the necessity of the following contents: (i) preparing cost reports and (ii) providing information for decisionmaking. The results from Table 4 show that the finance department said that it is necessary to prepare cost reports for decision-making (with mean values of 3.45 to 4.05 ), in which making cost reports based on the cost factors had the highest agreement, followed by making reports based on the cost for one student and for each department (unit and faculty), with mean values of 3.96 and 3.85 respectively.

Regarding frequency (see Figure 1), three types of reports that have the highest level of the agreement are reported by departments and students, by variable and fixed costs, and by factors (from $47 \%$ to $53 \%$ ). Reporting by factors and by departments had the response of "strongly agree" with rates of $29 \%$ and $27 \%$ respectively. The reporting by controllable and uncontrollable costs had the lowest rate of agreement, and the response rate for "disagree" was about $13 \%$. The necessity of providing information on CVP analysis for

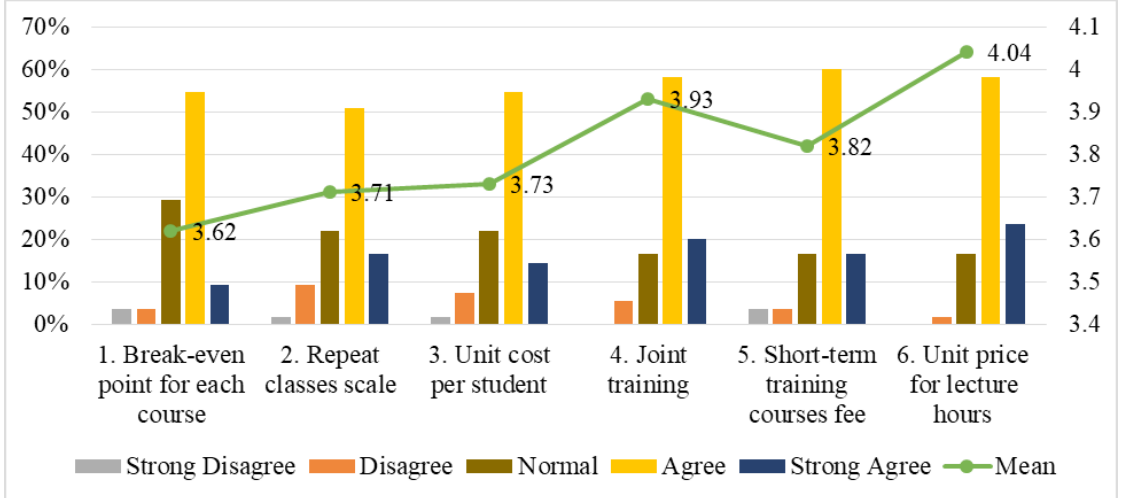

Figure 1: Compare CVP analysis information by frequency and average value

Table 4: Requirements on cost reporting

\begin{tabular}{|l|c|c|c|c|c|c|c|c|}
\hline \multicolumn{1}{|c|}{ Report } & \multirow{2}{*}{ N } & \multirow{2}{*}{ Mean } & \multicolumn{6}{c|}{ Percentage (\%) } \\
\cline { 5 - 10 } & & & S1 & S2 & S3 & S4 & S5 & S4 \& S5 \\
\hline By variable costs and fixed costs & 55 & 3.75 & 0.0 & 7.30 & 27.30 & 49.10 & 16.40 & 65.50 \\
\hline By direct and indirect costs (per student) & 55 & 3.96 & 0.0 & 5.50 & 20.00 & 47.30 & 27.30 & 74.60 \\
\hline By direct and indirect costs (per department) & 55 & 3.85 & 0.0 & 10.90 & 12.70 & 56.40 & 20.00 & 76.40 \\
\hline By factors (salary, scholarship, outside services & 55 & 4.05 & 1.80 & 1.80 & 14.50 & 52.70 & 29.10 & 81.80 \\
\hline By controllable and uncontrollable cost & 55 & 3.45 & 0.0 & 12.70 & 36.40 & 43.60 & 7.30 & 50.90 \\
\hline
\end{tabular}

Notes: S1 (Strong Disagree) and S5 (Strong Agree) 
administrators' decision-making is shown in Figure 2 and Table 5.

In terms of mean values (Table 5), respondents agreed on the information provided for administrators' decisionmaking, with mean values ranging from 3.91 to 4.04 . The information to achieve the targeted profit was appreciated the most (with a mean value of 4.04), and the remaining information such as break-even point and analysis of changes in costs, volume, and profit had similar mean values (3.91 and 3.95). In terms of frequency, all information had a high level of "agree" and "strongly agree", with rates from $69.1 \%$ to $80 \%$ (see Figure 3).

Table 5: Requirements for decision making

\begin{tabular}{|l|c|c|c|c|c|c|c|c|}
\hline \multicolumn{1}{|c|}{ Making decision } & \multirow{2}{*}{ N } & \multirow{2}{*}{ Mean } & \multicolumn{5}{c|}{ Percentage (\%) } \\
\cline { 6 - 10 } & & & S1 & S2 & S3 & S4 & S5 & S4 \& S5 \\
\hline Breakeven point information & 55 & 3.91 & 0.0 & 1.8 & 29.1 & 45.5 & 23.6 & 69.1 \\
\hline Information to achieve the target profit & 55 & 4.04 & 0.0 & 1.8 & 18.2 & 54.5 & 25.5 & 80.0 \\
\hline $\begin{array}{l}\text { Analysis of changes in costs, volumes and } \\
\text { profits }\end{array}$ & 55 & 3.95 & 0.0 & 0.0 & 27.3 & 50.9 & 21.8 & 72.7 \\
\hline
\end{tabular}

Notes: S1 (Strong Disagree) and S5 (Strong Agree)

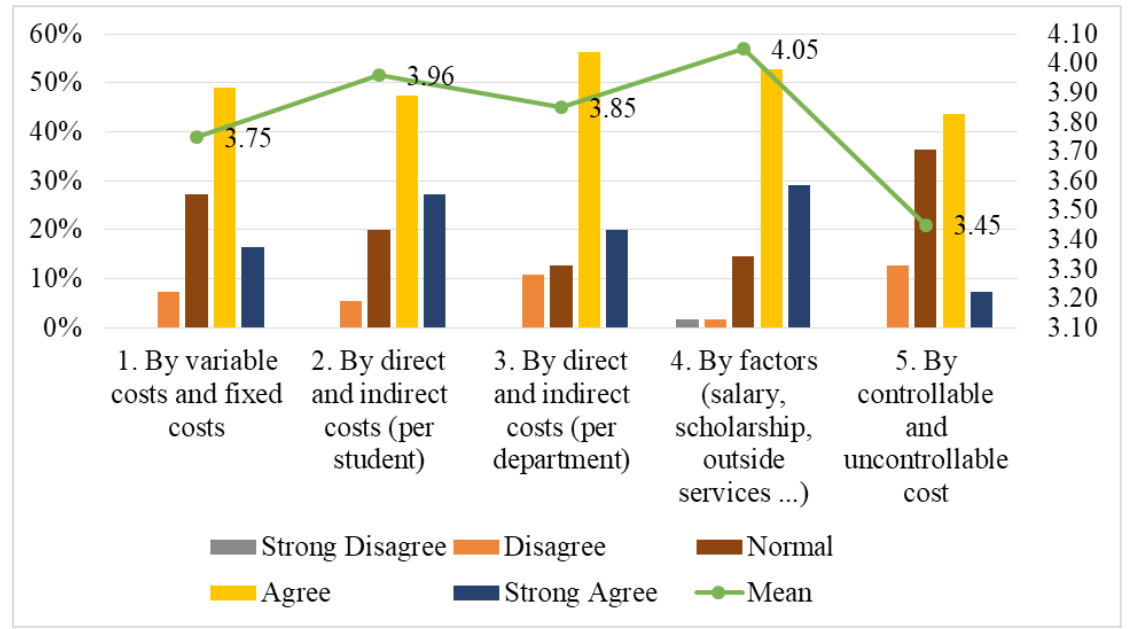

Notes: S1 (Strong Disagree) and S5 (Strong Agree)

Figure 2: Cost reporting requirements by frequency and average value

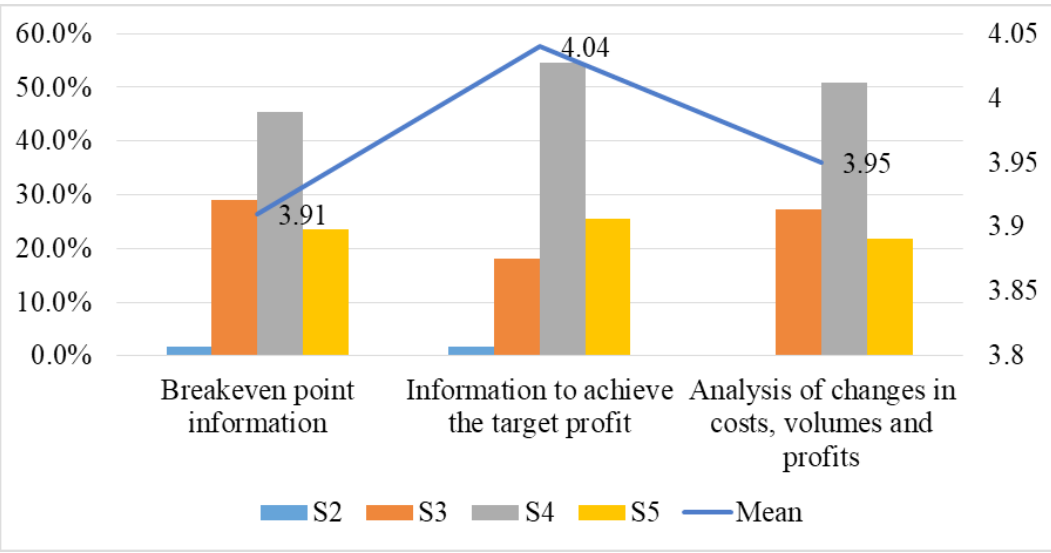

Notes: S1 (Strong Disagree) and S5 (Strong Agree)

Figure 3: Decision-making information requirements by frequency and average 


\section{Discussion and Recommendations}

\subsection{Discussion}

The survey on the CVP analysis in public universities in Vietnam shows that universities used information from this analysis in making decisions: cost classification and determining break-even point, the number of students, and determining the wage of teachers. The research results are explained as follows:

\section{Regarding cost recognition.}

The finance department of universities tracked cost factors separately, such as expenses for teachers (salaries, bonuses, allowances, etc.), expenses for students (scholarships, cultural activities, and sports), administrative expenses, expenses for teaching, scientific research, procurement, and the repair of assets. The distribution of general expenses to provide appropriate cost information to subjects bearing costs are made based on flexible criteria; accordingly, each type of cost has a reasonable allocation. From tracking these types of expenses, the finance department prepares cost reports to provide useful information about the amount and rate of each type of cost in total costs. In particular, controllable and uncontrollable costs, which are essential in cost control, are monitored better by totally autonomous universities than other groups of universities, which account for $90 \%$ of the studied universities of this paper.

\section{Regarding information from the CVP analysis for decision-making.}

According to the survey results, the finance departments provide basic information for administrators, such as wages of teachers, joint training, sizes of repeat classes, and training costs for each student. Information such as break-even points of joint programs and repeat classes are also provided by the finance department to the administrators to make appropriate decisions. This is relevant information for administrators in making decisions. When comparing the degrees of autonomy of the studied universities, all universities are concerned and use CVP information. Specifically, totally autonomous universities are more likely to provide and use such information. This proves that the CVP analysis is more useful to administrators when universities are more autonomous.

Apart from certain achievements, the CVP analysis of universities still has limitations. This information tends to mostly feature financial accounting information, reducing the role of providing information to administrators; specifically:

\section{Regarding cost classification of cost reporting.}

The cost classification and cost reporting for administrators' decision-making are neither comprehensive nor coordinated. The finance department of universities only tracks cost factors such as salaries, scholarships, outside services, etc. (according to the state budget index). Along with the cost classification, $100 \%$ of universities pay great attention to the cost reporting by factor. The types of costs needed for management reports, such as variable and fixed costs; direct and indirect costs for one student or for departments; and controllable and uncontrollable costs are not provided regularly. Totally autonomous universities make these reports at the lowest level (from $24 \%$ to $40 \%$ ) compared to the other two groups. These reports, which provide useful information for administrators in making decisions, are not prepared regularly in public universities. Information on variable costs and fixed costs serves as a basis for decision making with additional options; direct and indirect costs for each student serve as a basis for determining break-even points of training courses, training majors, and joint programs; direct and indirect costs for each department serve as a basis for decision making and cost control for each department, faculty, discipline, and campus.

In addition, general cost allocation is always a complicated issue for management accounting. Universities classify costs based on flexible criteria. Classification of costs based on the number of students of the entire university accounts for $40 \%$. However, classification of costs based on the number of students enrolled in courses; the classification of costs based on the number of staff working in departments is not used much (from $67.3 \%$ to $81.8 \%$ ). In summary, the cost classification and making cost reporting for administrators' decision-making are neither comprehensive nor coordinated. The reports only track costs factors while other information for cost control such as controllable and uncontrollable costs and direct and indirect costs for each department is not provided nor addressed by accountants.

\section{Regarding information from CVP analysis for decision making.}

Universities do not track costs separately for longterm and short-term training activities under contracts with campuses and short-term classes nor for each discipline. Therefore, it is difficult to control costs, and there are certain limitations in the provision of information to administrators to make decisions in signing contracts, opening training classes, and determining the number of students of each discipline to achieve optimal efficiency. Information related to decision making of short-term training courses, joint training courses, repeat classes (the size and break-even points thereof), cost per student, and wage of teachers are not prepared regularly; in particular, information which is not used often is the break-even point for each course (with the mean value of 3.62). 


\subsection{Recommendations}

\subsubsection{Regarding Cost Classification and Cost Reporting}

Costs of activities in universities of universities can be divided into types of costs providing management accounting information such as dividing costs into variable costs, and fixed costs which is the initial basis to implement the application of management accounting. Variable costs are understood as the total costs that in terms of value vary according to the level of activities (salaries paid to lecturers, support for students). Fixed costs are costs which do not change in terms of value within certain capacity such as the depreciation of lecture halls, salaries paid to administrators. After classifying costs, accountants can provide information about break-even points for each class, course, and discipline. Therefore, the paper proposes the classification of costs of universities as follows:

\section{Classification of fixed and variable costs}

Fixed costs include depreciation of lecture halls, depreciation costs of machinery and equipment (facilities, cars, teaching equipment), expenses for basic salaries, expenses for hiring security guards and sanitation costs which fixed periodically. Variable costs include services purchased from outside electricity, water, lecture halls); wages paid to lecturers; overtime wages paid to lecturers. The fixed cost is characterized by the lecture hall used for various time slots that should use the straight-line depreciation rate; then, the depreciation expense for lecture halls, machinery, and cars will be fixed under certain conditions. This means that, when the income reaches the break-even point, the additional income will only need to offset the variable costs, and the university will start to have profits. Therefore, in the annual estimation plan, it is necessary to take into account the diversity of tuition revenues of the system by year, calculating the break-even point. If the break-even income is exceeded, the additional income after subtracting variable expenses should increase with respect to interest.

Fixed and variable costs should be tracked separately by department, course, discipline, and joint program. The more detailed the level of cost reporting, the more helpful the information will be to calculate the results, such as calculating interest for each joint program, course, and discipline. The accounting department of the schools can track details receivables for each year, each program, and from scientific research. After subtracting the corresponding variable costs for each subject (class, course, discipline, etc.) and separate fixed costs (if any), the result will be the corresponding interest of each subject as a basis for efficiency evaluation of the estimation or implementation.

\section{Classification of direct and indirect costs for each student}

The costs for each student include all lecturers' salaries, expenses directly and indirectly related to teaching. In which, the direct costs are costs directly related to the number of students such as: Wages for lecturers' lessons, which are determined based on the assignment of the faculty and the corresponding confirmation of lecturers; depreciation expenses of items such as offices, computer rooms, classrooms are determined by table of allocation and depreciation rates; scholarships are determined based on the list provided by the student affairs department and the specified scholarship amount, and other expenses such as teaching equipment, drinking water are determined by on the specified amount established by the universities. Indirect costs are costs related to many students, which need to be allocated such as: salaries of staff, managers, which are determined by payroll standards; depreciation of offices are determined based on the allocation and depreciation rates; other expenses are determined based on actual usage. With this classification, the university can collect information and evaluate the results of each class, program, and course.

\subsubsection{The Application of CVP Analysis in Making Short-Term Decisions}

Currently, universities should examine activities from many perspectives to find the optimal training system. For universities, the cost-volume-profit model can help to determine the minimum number of courses required to offset the costs. This is a useful tool that can help university administrators to select relevant information in making decisions. It is not only helpful in designing training programs and implementing new strategies, but it also helps universities to consider possible risks. The application of the information in making short-term decisions can be explained as follows:

Determining break-even points for each class, course, and discipline: the universities should determine details about numbers of students to reach the break-even point and required fees to meet break-even points. Then, university administrators can make decisions about whether to keep certain classes or not. The number of students and required fees to meet break-even points are necessary to set targets for each class, course, and discipline and financial targets of the university. The determination of break-even points is important to IT and language centers, which provide certificates of competence for students to meet the graduation requirements of the university. Furthermore, universities have certain centers that help their directors to determine the minimum number of students required for each class. The application of cost-volume-profit analysis helps universities 
to establish indicators such as the contribution margin and leverage to evaluate the training activities and create appropriate strategies and implementations thereof.

Determining the cost for each student in each class and year helps university administrators make the right decision about the training scale for each school year. The costs of the student training programs should be determined accurately to evaluate the efficiency of each program (revenues and corresponding costs). Costs for each program include expenses such as wages paid to lecturers, general costs (including general administrative costs).

In conclusion, in the context of the autonomy of public universities in Vietnam, the management required to improve the quality is necessary and contributes to reducing the costs and increasing the revenue to provide the best services to students. Flexible applications of management accounting contribute to providing relevant information for administrators in making wise decisions.

\section{References}

Abdullahi, S. R., Bello, S. B., Mukhtar, I. S., \& Musa, M. H. (2017). Cost-Volume-Profit Analysis as a Management Tool for Decision Making In Small Business Enterprise within Bayero University, Kano. IOSR Journal of Business and Management, 19(2), 40-45. DOI: 10.9790/487X-1902014045.

Agasisti,T.,\& Johnes, G.(2010). Heterogeneity and the Evaluation of Efficiency: the Case of Italian Universities. Applied Economics, 42(11), 1365-1375, DOI: $10.1080 / 00036840701721463$.

Alibekova, G., Tleppayev, A., Medeni, T., \& Ruzanov, R. (2019). Determinants of Technology Commercialization Ecosystem for Universities in Kazakhstan. Journal of Asian Finance, Economics and Business, 6(4), 271-279. https://doi. org/10.13106/jafeb.2019.vol6.no4.271.

Bauer, K., \& Bauer, M. (2018). Possibilities to control volume of production in cvp analysis: an example of companies providing taxi services. The 6th International Scientific Conference IFRS: Global Rules and Local Use (trang 296-308). Prague: Biblioteka Politechniki Krakowskiej. http://suw.biblos.pk.edu. $\mathrm{pl} /$ browseByAuthor \&db=BPP.

Buşan, G., \& Dina, I.-C. (2009). Using cost-volume-profit analysis in decision making. Annals of the University of Petroșani, Economics, 9(3), 103-106.

Cropper, P., \& Cook, R. (2000). Developments: Activity-Based Costing in Universities - Five Years On. Public Money \& Management, 20(2), 61-68. https://doi.org/10.1111/14679302.00213.

Enyi, E. P. (2019). Joint Products CVP Analysis - Time for Methodical Review. Journal of Economics and Business, 2(4), 1288-1297. DOI: 10.31014/aior.1992.02.04.168.

Gean, F., \& Gean, V. (2015). The Desirability of an Integrated Learning Methodology for Enriching CVP Analysis. Journal of Business and Accounting, 8(1), 127-137.
Goddard, A. (2006). Accounting and NPM in UK local government - contributions towards governance and accountability. Financial Accountability \& Management, 21(2), 191-218. https://doi.org/10.1111/j.1468-0408.2005.00215.x.

Government. (2015, 2 14). Decree No. 16/2015/ND-CP of the Government: Regulating the autonomy mechanism of public non-business units public non-business units. Retrieved March 1 2019, from Electronic information of the Government: http://vanban.chinhphu.vn/portal/page/portal/chinhphu/ hethongvanban?class_id=1\&

Jiang, Y., \& Shen, Z. (2017). Study on the Application of CVP Analysis in Catering Industry. The 2nd International Conference on Contemporary Education, Social Sciences and Humanities (ICCESSH 2017), https://doi.org/10.2991/ iccessh-17.2017.195.

Kaplan, R. S., \& Atkinson, A. (2007). Advanced Management Accounting. New York, NY: Prentice Hall International, Inc. ISBN 10: 0132622882 ISBN 13: 9780132622882. Third edition.

Kim, S. H. (2015). Cost-Volume-Profit Analysis for a MultiProduct Company: Micro Approach. International Journal of Accounting and Financial Reporting, 5(1), 23-35. DOI: 10.5296/ijafr.v5i1.6832.

Le, D. Q. (2017). Management accounting - the tool to implement financial autonomy at public universities. Finance Magazine, 6, 78-79.

Liu, L.-L. S., Forgione, D., \& Younis, M. (2012). A comparative analysis of the CVP structure of nonprofit teaching and forprofit non-teaching hospitals. Journal of Health Care Finance, 39(1), 12-38.

Lulaj, E., \& Iseni, E. (2018). Role of Analysis CVP (Cost-VolumeProfit) as Important Indicator for Planning and Making Decisions in the Business Environment. European Journal of Economics and Business Studies, 4(2), 99-114. DOI: 10.26417/ ejes.v4i2.p99-114.

Nguyen, M. T., \& Nguyen, H. V. (2015). Textbook of Survey Methods: Principles and practice. Hanoi: National Economics University Publishing House.

Nguyen, T. Q., \& Nguyen, H. T. (2020). Factors Affecting Industry and University Collaboration in Education in the Hospitality Industry in Vietnam: A Business Perspective. Journal of Asian Finance, Economics and Business, 7(2), 291-300. https://doi. org/10.13106/jafeb.2020.vol7.no2.291.

Philbin, S. (2011). Design and implementation of the Balanced Scorecard at a university institute. Measuring Business ExcellenceThe journal of business performance management, 15(3), 34-45. https://doi.org/10.1108/13683041111161148.

Phillips, P. (1994). Welsh Hotel: Cost-Volume-Profit Analysis and Uncertainty. International Journal of Contemporary Hospitality Management, 6(3), 31-36. https://doi. org/10.1108/09596119410059236.

Punniyamoorthy, R. (2017). Examining Cost Volume Profit and Decision Tree Analysis of a Selected Company. World Wide 
Journal of Multidisciplinary Research and Development, 3(9), 224-233. www.wwjmrd.com International Journal.

Sabri, M. F., Cook, C., \& Gudmunson, C. (2012). Financial well-being of Malaysian college students. Asian Education and Development Studies, 1(2), 153-170. https://doi. org/10.1108/20463161211240124.

Stoenoiu, C.-E. (2018). Sensitivity of indicators used in costvolume-profit. MATEC Web Conf., 184 (2018) 04003 Annual Session of Scientific Papers IMT ORADEA 2018, pp.1-6. https://doi.org/10.1051/matecconf/201818404003.

Tran, C. D. (2016, 9 2). Management accounting for public nonbusiness units in an integrated economy. (Information agency of the Ministry of Finance) Retrieved March 5 2019, from Electronic Journal of Finance: http://tapchitaichinh.vn/taichinh-kinh-doanh/tai-chinh-doanh-nghiep/ke-toan-quan- tridoi-voi-don-vi-su-nghiep-cong-lap-trong-nen-kinh-te-hoinhap-111210.html
Upping, P., \& Oliver, J. (2012). Thai Public universities: mordernisation of accounting practices. Journal of Accounting \& Organizational Change, 8(3), 403-430. https://doi. org/10.1108/18325911211258362.

$\mathrm{Vu}$, T. T. (2017). Financial Management in Vietnamese public universities, Monographs. Hanoi, Vietnam: Finance Publishing House.

Witte, K. D., \& López-Torres, L. (2015). Efficiency in Education. A Review of Literature and a Way Forward. Documents de treball d'economia de l'empresa (trang 1-40). Barcelona: Departament d'Empresa, Universitat Autònoma de Barcelona.

Zulfaris, M. D., Mustafa, H., Mahussin, N., Alam, M., \& Daud, Z. M. (2020). Students and Money Management Behavior of a Malaysian Public University. Journal of Asian Finance, Economics and Business, 7(3), 245-251. https://doi. org/10.13106/jafeb.2020.vol7.no3.245. 